\title{
"A Brilliant Invention:" Representations of London in Ian McEwan and Graham Swift
}

\author{
Dr Anastasia Logotheti \\ Associate Professor, Department of English \\ DEREE-The American College of Greece
}

\begin{abstract}
Ian McEwan's Saturday (2005) and Graham Swift's Last Orders (1996) and The Light of Day (2003) are English novels which follow the modernist trope of one-day-in-the-life-of-city-dwellers and which are set in the metropolitan canvas of contemporary London. These novels explore intricate stories of domestic confrontations which intertwine with the histories of international hostilities. The urban spaces the characters obsessively claim as their own are treated as palimpsests which hide and reveal past traumas. Focusing on narrated space to foreground the structure of each of these works, this essay explores representations of London and its denizens in a post-9/11 world to consider how the depiction of urban spaces reveals and conceals narratives of lives both ordinary and extraordinary in works by major contemporary novelists Ian McEwan and Graham Swift.
\end{abstract}

Keywords: Ian McEwan, Graham Swift, contemporary literary novels, London in literary fiction.

\section{Introduction}

Three contemporary English novels set in the larger metropolitan canvas of contemporary London are Graham Swift's Last Orders (1996) and The Light of Day (2003) as well as Ian McEwan's Saturday (2005). Self-conscious architects of narratives situated within various urban spaces, Swift and McEwan fabricate social environments of failure and success in which characters conceptualize themselves as city dwellers. Navigating cars and shopping carts through congested cityscapes, these characters examine connections, personal and communal, while they rediscover the city of London as "a brilliant invention" (McEwan 5).

In Last Orders four men embark on a journey to fulfil the dying wish of a companion, transporting his ashes in a royal blue Mercedes from Bermondsey, in South London, to Margate, in Kent. In The Light of Day, the narrator, George, is a Wimbledon private investigator who catalogues the streets he walks, the shops and cafés he patronizes, commenting on the Marrakesh-themed window display of the Tanning Centre, the "pseudoVictorian feel" of Gladstone's, and the "Latin-American beat" of the Café Rio. As shopkeepers or as patrons of shops on the High Street, the men of Swift's fiction document life through images of commerce. In similar mode, in the "spirit of aggressive celebration of the times," McEwan's protagonist in Saturday, Henry Perowne, neurosurgeon extraordinaire, resides in Fitzrovia, walks from his expansive home to the hospital where he operates, and drives a "silver Mercedes S500 with cream upholstery" (75).

This essay explores representations of London in three English novels which depict lives both ordinary (in Swift's works) and extraordinary (in McEwan's work). Set in a city which "lie[s] wide open, impossible to defend" (McEwan 276), these novels reveal how the depiction of urban spaces in contemporary literature exposes the constant negotiation between city dwellers and the metropolis. The particular novels are chosen not only because they are recently published works of authors recognized as members of the British literary establishment. McEwan and Swift are also authors who engage directly with issues of identity: personal, national, and global. The precise urban geography meticulously mapped and described in these novels suggests that the identity of the city dweller is inexorably linked with the particular place and time. Thus, the local and the global unite through narratives deeply engaged with questions of Englishness and cosmopolitanism, narratives which pay homage to the condition-of-England tradition. Furthermore, the modernist trope of a plot which focuses on one-day-in-the-life of the main characters, which all three works follow, allows aspects of social realism to be explored by traversing an inner landscape of consciousness. By replacing the traditional expansiveness of narrative time in the novel with the limited space of one day, Swift and McEwan choose memory over experience thus foregrounding interiority and subjectivity, making space function metonymically and symbolically. 


\section{The Three Novels}

This essay will examine each of the three novels in turn, focusing on narrated space and on structure to foreground the architecture of each of these works.

\subsection{Graham Swift, Last Orders}

Set on 2 April 1990, Swift's Booker-prize-winning sixth novel demonstrates the interrelatedness of physical space and human activity. The novel concerns a day of mourning which develops into a cathartic ritual of remembrance: four men embark on a car journey from Bermondsey, in South London (SE1), to Margate, in Kent, in order to honor, as the title implies, a final request. Three ageing friends, Ray Johnson, Vic Tucker, Lenny Tate, and Vince Dodds, the deceased's adopted son, drive east to scatter the ashes of Jack Dodds, a butcher. As this quartet of quarreling companions navigates through city and country roads and makes numerous detours to cater for needs both physical and emotional, their past lives, frustrated aspirations, and clandestine relationships are gradually revealed.

The Bermondsey community explored in Last Orders is meticulously localized. Chronology and geography conflate so that the local and the global are encapsulated in the here-and-now. Swift examines the repercussions of chance and choice on the lives of a close-knit community of men and their families, who have been brought together by circumstances of geography, age, and social class. In the novel these city dwellers still idealize their dwelling: they revere both their home and their land, but their pilgrimage is only a nostalgic gesture, a remnant of a romanticized past which they furtively embrace. The name "Thomas à Becket" (17), briefly glimpsed on a sign on the drive down the Old Kent Road, is a pub. That part of Southwark is mentioned in Chaucer, in the General Prologue of The Canterbury Tales, as "the watering of St Thomas," a regular stop for pilgrims. In Chaucer's time a pilgrimage was an arduous journey, as much an act of piety as it was an act of penitence undertaken, physically and spiritually, as ritual.

The collective memory of a dying generation that came of age during World War II is encompassed in this Bermondsey-community mosaic of voices. As the different narratives progress, we engage in the narrative reconstructions of deeper wishes and resentments characteristic of Swift's method of creating motifs and interpretative layers. Narrating place is a highly complex task in this novel which is constructed out of seventyfive sections of varying length as a chronologically forward-moving plot is constantly interrupted by past reminiscences. Through constant flashbacks, the narrators comment on events in the past six decades following a pattern carefully prepared and executed. Most sections in the novel, fifty-eight to be exact, are headed by the names of characters, specifying the narrator of these sections. While the place-entitled sections move the plot towards Margate, the various name-headed monologues provide commentary on events of the past or the present, explaining the actions of characters.

Fittingly for a novel identified with urban spaces, Last Orders makes a symbol out of automobiles: Vince is into "wheels" (105); he "can't imagine a world without motors" (71). Vehicles enabling any type of escape from the demands of human relationships acquire a sinister dimension in the novel. For instance, Ray's camper allows Vince to remove himself from the Dodds family environment, provides the excuse for Ray's wife to abandon an unhappy marriage, and becomes the location of Amy's brief liaison with Ray. Similarly, Jack takes the meat van to Smithfield during the week and to Margate on Sundays in a sustained effort to avoid assuming responsibility for their institutionalized child although his wife travels on a bus to visit her twice a week. The desire for travel and machines represents escape. Vince considers his car "a comfort and companion" (71). Since he connects the Dodds household with emotional demands, his home is each car he repairs, drives, and sleeps in. Unsurprisingly, he also likes "doing it in cars" (103): for Vince this kind of sex, "cramped and squashed and hasty" (103), guarantees lack of intimacy and underlines his fear of commitment.

However, the mobility that vehicles offer is as illusory as the ability of The Coach and Horses (the name of the neighborhood pub) to travel anywhere. Until these characters consider where "we've all got to get to that the coach should be taking us" (9), they do not cover any ground despite the miles they place between themselves and the unacknowledged geographies which tie them to the flow of people and spaces in the contemporary world. In Last Orders Swift's characters escape through travel until they reach the end of Margate pier and learn to reconcile themselves to their abode. 


\subsection{Graham Swift, The Light of Day}

Swift's seventh novel The Light of Day (2003) is set in South London suburbia, the "leafy, looked-after, quiet zone of houses set back from the street" (19), and again focuses on one day: 20 November 1997 is the second anniversary of the death of Robert Nash. In 1995 he was murdered by Sarah, his wife of twenty-four years, in the kitchen of their Wimbledon home. In the course of the day the narrator, fifty-year-old George Webb, visits the grave in the morning then calls on the widow in prison in the afternoon before returning to the scene of the crime in the early evening. As George moves from cemetery to penitentiary to the old Nash residence, the novel demonstrates that our conception of space is relational.

The Light of Day concerns four couples: George Webb and his wife; his parents, Jane and Frank Webb; Sarah and Robert Nash; the Empress Eugenie and Napoleon III. Adultery is a common occurrence in these marriages: these husbands are not the only ones who cheat on their wives. As a private investigator George specializes in "matrimonial work" (78), providing photographic evidence of infidelity to frustrated wives. Sarah Nash hires Webb to follow her husband and his lover, Kristina Lazic, a twenty-three year-old Croatian refugee, to Heathrow airport to verify that she is departing and their affair is ending. After Heathrow George continues to follow Nash who drives to his ex-lover's apartment in Fulham. When Bob finally returns to Wimbledon that evening, after narrowly escaping a fatal car accident, "there's nothing left of him inside, he's drained away" (227). Through the Nash story the lives of the educated suburbanites appear as artificial as the constructed nature scenes in their well-tended gardens.

In the novel the aspirations and compromises of the denizens of post-Cold-War middle classes emerge. South Londoners Sarah and George grew up in Chislehurst and reside in Wimbledon, yet they belong to different worlds. His office is in "Wimbledon's lower end" while the Nash residence is in the "snooty Village on the hill" (19). They would never have met had Sarah not sought Webb's professional assistance. When she walks into "G. W. Investigations" on 26 October 1995, the forty-three year-old Sarah is a well-educated, uppermiddle-class college lecturer and translator married to a successful gynecologist; the forty-eight year-old George is a lonely and disgraced police detective now in private practice. Like his father, who was a photographer with a studio on Chislehurst High Street, George appropriates urban spaces as he recreates suburban lives engaging in processes of production and consumption identified with contemporary metropolitan life.

Another understanding of space emerges through Kristina's tale of exile. Coming from Croatia, Kristina is identified with war. A student in Sarah's English class, Kristina is an orphan given shelter at the spacious Nash home. She brings into the "nice, clean home" of her benefactors the "ruined streets" and "burnt-out houses" of the former Yugoslavia. The world of London suburbia is to her a fiction: "In Croatia you don't think of a street, a house in Wimbledon" (107). The Nash residence is defined by absence: the Nash's son lives in America, having removed himself, geographically and emotionally, from his parents' home. Eager to fill the void, Bob and Sarah adopt a surrogate daughter. Into their suburban castle, they bring a war orphan, to compensate for their loss. In return for their act of charity, they hope that this new child will spatially redefine their middle-age by inhabiting the gap. This reimagining of the present is narrated as story, through signs which signify both genre and geography: "once upon a time, it all began, with the best of intentions. . . A fairy-tale, a mini Switzerland" (218). For Kristina the loving shelter of a Wimbledon home is a place of exile: "this was her home now, her place, but it was as though she was trying not to be there. . . She just sat there, like a prisoner" (38). The Nash residence proves to be a fragile refuge. In the narrative present George imagines the world to which Kristina returned on the Dalmatian Coast as unaffected by war: "streets in Dubrovnik. In Croatian villages. Walls, yards, squares" (203). He imagines Kristina, unaware of the murder that occurred on the night of her departure, sitting at "some pavement café. Zagreb? Dubrovnik? Winter sunshine. Steaming coffee cups, glinting table tops" (107). The urban spaces which the characters in this novel claim and reject are treated as palimpsests which hide traumas of the past and expose their aspirations in the present.

Graham Swift, in conclusion, is a masterful builder of cityscapes. Intertwining the histories of international hostilities with stories of domestic warfare, his novels foreground the relationship between interior and exterior, domesticity and urbanity. Evoking the global by focusing on the local, Swift's London dwellers acknowledge the demands that the city places upon them but remain apprehensive of a cosmopolitan reality that might propel them into the future. As London morphs around them into a 21-century megapolis, Swift's Everymen glance 
away from change even when they proudly declare (in the words of the protagonist of Swift's 2014 short story "Going Up in the World") "My city, my London" (2).

\subsection{Ian McEwan, Saturday}

The home as sanctum sanctorum and the threat that life in the city poses to the urban dweller in a post-9/11 world constitute the context within which Ian McEwan's Saturday exposes the fragility of the contemporary metropolis. Referencing imminent terrorist threats to the West, the novel makes uncomfortable reading as its January-2005 publication uncannily predates the July-2005 London bombings. In predicting the 7/7 bombings Saturday proved to be depressingly precise: in the final pages the text announces that "London . . lies wide open, impossible to defend, waiting for its bomb" (276). One hundred pages earlier in the novel the certainty of a terrorist attack in the post 9/11 metropolis is termed "an inevitability," the "thread that binds the days" (176).

Before we realize the historic significance of the particular Saturday, McEwan allows the first few pages of the novel to present the protagonist as a city enthusiast:

Standing here, as immune to the cold as a marble statue, gazing towards Charlotte Street, towards a foreshortened jumble of façades, scaffolding and pitched roofs, Henry thinks the city is a success, a brilliant invention, a biological masterpiece. . . . And the Perownes' own corner, a triumph of congruent proportion; the perfect square laid out by Robert Adam enclosing a perfect circle of garden - an eighteenth-century dream bathed and embraced by modernity, by street light from above, and from below by fibre-optic cables, and cool fresh water coursing down pipes, and sewage borne away in an instant of forgetting. (5)

The 48-year old neurosurgeon Henry Perowne is a dweller who refuses to dwell much on those less fortunate unless he operates on them: he is enamored of medicine, his wife, Rosalind, who is a lawyer, his poet daughter and his musician son, even his "stabled" silver Mercedes. McEwan portrays him as a comfortable philistine but also as an admirable scientist: for most of the narrative suspense relates to the brain operations Perowne conducts, not his domestic affairs.

Like an architectural plan, the essentials of this novel are laid out for readers early so that we know what we are constructing within minutes of picking up the book. The title, Saturday, suggests that this novel documents only one day in the life of the Perowne family. The cover photograph of a familiar London landmark illuminated at night with a blazing, comet-like object about to explode into the BT Tower is the image we read about in the first few pages. Another photo, used for the cover of the international edition, shows a detail from the building and a male figure looking out onto the darkened square below. In a self-referential nod, which caused some controversy when the novel was published, McEwan gives Henry Perowne a residence exactly like his own at that time: a Regency house of 7,000 sq. ft. on the north side of Fitzroy Square. Designed by $18^{\text {th }}-\mathrm{c}$ star architect Robert Adams, the square is not just related to the history of London's transformation into a Victorian metropolis. As the only square in Fitzrovia, it is the public space nearest to and directly overlooked by the Post Office Tower, which, in Perowne's view, is a "valiant memorial to more optimistic days" (4).

Before the narrative even begins, McEwan suggests the theme as well as essential plot elements through the epigraph, which is an extended quotation from Saul Bellow's 1964 novel Herzog:

"What it means to be a man. In a city. In a century. In transition. In a mass. Transformed by science. Under organized power. Subject to tremendous controls. In a condition caused by mechanization. After the late failure of radical hopes. In a society that was no community and devalued the person."

Bellow died just months after the publication of Saturday and in his appreciation of the "Master,"1 McEwan credits him with "redefining the novel," suggesting not only Bellow's but also McEwan's own aspirations as a novelist. Setting the action right where he then resided and toying with the tradition of the novel and the conventions of social realism by opting for a third-person, limited-omniscient narrative voice, McEwan in Saturday rejects the exterior-interior binary, inviting us into the novelist's den to consider the city as fiction and to engage with history as story.

\footnotetext{
${ }^{1}$ This is the title of McEwan's tribute to Bellow published in the Guardian on 7 April 2005.
} 
The date this novel is set, Saturday, 15 February 2003, is initially not a day of personal significance (as in Swift's novels) but of national importance. More than a million people demonstrated in the streets of central London that day against the Blair / Bush invasion of Iraq; that Saturday march has been credited as the largest protest in British history. For McEwan's readers this is an ironic record as we know that the invasion did take place a little over a month later. McEwan's protagonist does not participate in the demonstration but streets closed off to traffic are partly responsible for a minor car accident Perowne has on his way to his weekly game of squash. Although Perowne manages to escape the three rather Pinteresque criminals riding in the BMW which collides with his Mercedes, the complacent physician realizes later that evening, when the same sociopathic trio invades his home and holds his entire family at knife point, that an invasion, national or domestic, is always a traumatic and life-changing experience.

McEwan may have chosen a protagonist who does not appreciate literature (allowing the perfect joke to develop between the novelist and the reader) but he allows Perowne to celebrate the comforts of the threatened metropolis as the antidote to the larger context of the city as a terrorist target and the locus of political decisions which threaten ordinary lives. By locating the action in the privileged center of London, by creating a threat, which is both domestic and imported, against the upper echelons of society, and then by constructing the invasion of the home as a micro-incident which evokes the macro-politics of West vs. East, McEwan exposes the vulnerability of London, the paradigmatic Western metropolis.

\section{Conclusion}

In these three works, therefore, the relationship between the human subject and the metropolis emerges as contested. By centering the city's appeal within its geography, these novels consider life in London in the $21^{\text {st }}$ century to have, to borrow a metaphor from Yeats, a "terrible beauty." The city dwellers in the fiction of Graham Swift and Ian McEwan must find their own ways to navigate a built environment which is sometimes hostile, at times alluring, and always inviting. The contemporary search for identity within this London, a literary megapolis which becomes a cosmopolis, is experienced, by the fictional characters and ourselves as readers, as both an invasion and an invention.

\section{References}

[1] Ian McEwan. Saturday. 2005. London: Vintage, 2006.

[2] Graham Swift. "Going Up in the World.” England and Other Stories. London: Simon \& Schuster, 2014.

[3] Graham Swift. Last Orders. London: Picador, 1996.

[4] Graham Swift. The Light of Day. London: Hamish Hamilton, 2003. 